\title{
Physical processes of cooling and mega-drought during the 4.2 ka BP event: results from TraCE-21ka simulations
}

\author{
Mi Yan ${ }^{1,2}$ and Jian Liu ${ }^{1,2,3}$ \\ ${ }^{1}$ Key Laboratory for Virtual Geographic Environment of Ministry of Education, State Key Laboratory of Geographical \\ Evolution of Jiangsu Provincial Cultivation Base, School of Geography Science, Jiangsu Center for Collaborative Innovation \\ in Geographical Information Resource Development and Application, Nanjing Normal University, Nanjing 210023, China \\ ${ }^{2}$ Open Studio for the Simulation of Ocean Climate Isotope, Pilot National Laboratory for Marine \\ Science and Technology, Qingdao 266237, China \\ ${ }^{3}$ Jiangsu Provincial Key Laboratory for Numerical Simulation of Large Scale Complex Systems, School of Mathematical \\ Science, Nanjing Normal University, Nanjing 210023, China
}

Correspondence: Jian Liu (jliu@njnu.edu.cn)

Received: 30 September 2018 - Discussion started: 11 October 2018

Revised: 5 February 2019 - Accepted: 5 February 2019 - Published: 12 February 2019

\begin{abstract}
It is widely believed that multi-decadal to centennial cooling and drought occurred from 4500 to $3900 \mathrm{BP}$, known as the $4.2 \mathrm{kaBP}$ event that triggered the collapse of several cultures. However, whether this event was a global event or a regional event and what caused this event remains unclear. In this study, we investigated the spatiotemporal characteristics, the possible causes and the related physical processes of the event using a set of long-term climate simulations, including one all-forcing experiment and four single-forcing experiments. The results derived from the allforcing experiment show that this event occurs over most parts of the Northern Hemisphere (NH), indicating that this event could have been a hemispheric event. The cooler NH and warmer Southern Hemisphere $(\mathrm{SH})$ illustrate that this event could be related to the slowdown of the Atlantic Meridional Overturning Circulation (AMOC). The comparison between the all-forcing experiment and the single-forcing experiments indicates that this event might have been caused by internal variability, while external forcings such as orbital and greenhouse gases might have modulation effects. A positive North Atlantic Oscillation (NAO)-like pattern in the atmosphere (low troposphere) triggered a negative Atlantic Multi-decadal Oscillation (AMO)-like pattern in the ocean, which then triggered a circum-global teleconnection (CGT)like wave train pattern in the atmosphere (high troposphere). The positive NAO-like pattern and the CGT-like pattern are the direct physical processes that led to the NH cooling and
\end{abstract}

mega-drought. The AMO-like pattern played a "bridge" role in maintaining this barotropic structure in the atmosphere at a multi-decadal-centennial timescale. Our work provides a global image and dynamic background to help better understand the $4.2 \mathrm{ka} \mathrm{BP}$ event.

\section{Introduction}

Understanding the characteristics and mechanisms of climate changes during the Holocene can help predicting future changes. The multi-decadal to centennial abrupt climate change or the rapid climatic change during ca. 4.5-3.9 ka (before $1950 \mathrm{CE}$ ), the so-called " $4.2 \mathrm{kaBP}$ event", was one of the major climate events during the Holocene (Mayewski et al., 2004; Staubwasser and Weiss, 2006; Wang, 2009, 2010). This event is considered to be closely linked to the cultural evolutions of different regions of Eurasia such as the collapse of the Akkadian empire, the termination of the urban Harappan civilization in the Indus valley and the collapse of $\mathrm{Ne}$ olithic cultures around the Central Plain of China (Weiss et al., 1993; Weiss and Bradley, 2001; Wu and Liu, 2001, 2004; Staubwasser et al., 2003; An et al., 2005; Staubwasser and Weiss, 2006; Liu et al., 2013; Weiss, 2015, 2016). Moreover, this event is also thought to be the transition of the Middle to Late Holocene (Walker et al., 2012; Finkenbinder et al., 2016). However, the characteristics, causes and corresponding mechanisms behind this event remain unclear. 
The $4.2 \mathrm{kaBP}$ event is mostly characterized by rapid events at various latitudes (Jansen et al., 2007), e.g., cooling in Europe (Lauritzen, 2003), centennial mega-droughts in North America (Booth et al., 2005), decreased precipitation in both southern and northern China (Tan et al., 2008), and the weakened summer monsoon in India (Nakamura et al., 2016); however, the manifestation of this event is far from convincing and needs more evidence and simulation investigations (Roland et al., 2014). Many reconstructions have shown that the $4.2 \mathrm{ka} \mathrm{BP}$ event is dominated by megadroughts at a centennial scale over mid- to low latitudes (Tan et al., 2008; Yang et al., 2015; Weiss, 2016). However, Roland et al. (2014) found no compelling evidence, at least in peatland records, to support that there was a $4.2 \mathrm{ka} \mathrm{BP}$ event in Great Britain and Ireland. Moreover, according to the hydrologic cycle (i.e., the hydroclimate changes are often regionally specific), it cannot be ruled out that there were no flooding events somewhere else during this period. For example, Huang et al. (2011) and Tan et al. (2018) found that successive floods occurred over the middle reaches of the Yellow River in China in association with the abrupt climatic event of $4.2 \mathrm{ka} \mathrm{BP}$.

Understanding the causes and mechanisms of the $4.2 \mathrm{kaBP}$ event can provide explanations for the reconstructed discrepancies over different regions. For the causes of the event, some reconstruction and modeling studies have suggested that solar irradiance could have played an important role in Early Holocene climate changes (Wang et al., 2005; Rupper et al., 2009; Owen and Dortch, 2014); however, no strong evidence has shown that the solar irradiance affected glacier fluctuations (cooling events) in the Late Holocene since there is as yet no good mechanistic explanations of how small changes in solar irradiance could significantly affect large-scale climate changes (Solomina et al., 2015). Tan et al. (2008) thought that the $4.2 \mathrm{kaBP}$ event could have been induced by the southward shift of the Intertropical Convergence Zone (ITCZ) and oceanic sea surface temperature (SST) changes, as well as the vegetation feedback caused by the solar activity. Liu et al. (2013) and Deininger et al. (2017) argued that the atmospheric circulation, such as the North Atlantic Oscillation (NAO)-like pattern but on a centennial timescale, could have played a more important role than the ocean circulation in this event, although the mechanisms that forced the circulation change remained unclear. A new reconstruction study has also shown that the dry phases over the western Mediterranean in the period of 4.5-2.8 ka generally agreed with positive NAO conditions (Ramos-Román et al., 2018). However, studies come to different conclusions on the likely phase of the NAO-like pattern during the Late Holocene (Finkenbinder et al., 2016). Some studies show positive NAO-type patterns during the Late Holocene (Tremblay et al., 1997; Sachs, 2007; RamosRomán et al., 2018), whereas others show negative NAO-like patterns (Rimbu et al., 2004). Since the mechanisms could be a complex set of air-sea interactions (Roland et al., 2014), it is hard for reconstruction to provide a general record due to its limitations such as interpretation and spatial incompleteness. The mechanisms behind the $4.2 \mathrm{ka} \mathrm{BP}$ event need to be clarified.

Therefore, to improve understanding of the $4.2 \mathrm{kaBP}$ event, new high-resolution reconstruction studies that focus on the $4.2 \mathrm{ka} \mathrm{BP}$ event are required. On the other hand, physically based modeling research can provide general concepts of the characteristics of the event along with the causes and the mechanisms. Climate simulations have been conducted to investigate another abrupt cooling event in the Early Holocene, the so-called $8.2 \mathrm{ka}$ event. The simulations were used to test the hypothesis raised by the reconstruction studies that the $8.2 \mathrm{ka}$ event was most likely caused by freshwater forcing and was associated with a weakening of the Atlantic Meridional Overturning Circulation (AMOC) (Alley and Agustsdottir, 2005; Ljung et al., 2008; Morrill et al., 2013, 2014; Wagner et al., 2013; Matero et al., 2017). For example, the simulations argued that the meltwater from the collapse of the ice dome over Hudson Bay was an essential forcing of the $8.2 \mathrm{ka}$ event (Wagner et al., 2013; Matero et al., 2017). However, little modeling work has been applied to the $4.2 \mathrm{ka}$ BP event.

Recently, Ning et al. (2019) briefly compared the spatial patterns of climate change in the ninth and fifth millennia BP using a set of transient modeling results in a long-term perspective. In the present study, we will use the same set of simulation results to provide in-depth characteristics of the 4.2 ka BP event and will focus on the possible causes and mechanisms behind this event. The model and experiments are introduced in Sect. 2. The results are shown in Sect. 3. The possible causes and mechanisms are discussed in Sect. 4, and conclusions are drawn in Sect. 5.

\section{Model and experiments}

A set of transient simulations (TraCE-21ka, Simulation of Transient Climate Evolution over the past 21000 years; He, 2011) conducted with the Community Climate System model version 3 (CCSM3) was used to investigate the spatial and temporal characteristics of the $4.2 \mathrm{kaBP}$ event and to determine the possible causes and mechanisms behind this event. The experiments are listed in Table 1, including one transient experiment with all forcings (TraCE-ALL), one singleforcing experiment forced only by transient orbital variation (TraCE-ORB), one single-forcing experiment forced only by transient meltwater flux (TraCE-MWF), one singleforcing experiment forced only by a quasi-transient ice sheet (TraCE-ICE) and one single-forcing experiment forced only by transient greenhouse gas concentrations changes (TraCEGHG). The simulations were conducted from $22000 \mathrm{BP}$ to $1990 \mathrm{CE}$ for the TraCE-ALL, the TraCE-ORB and the TraCE-GHG experiments and from $19000 \mathrm{BP}$ to $1990 \mathrm{CE}$ for the TraCE-MWF and the TraCE-ICE experiments. 
(a) Orbitally induced summer insolation

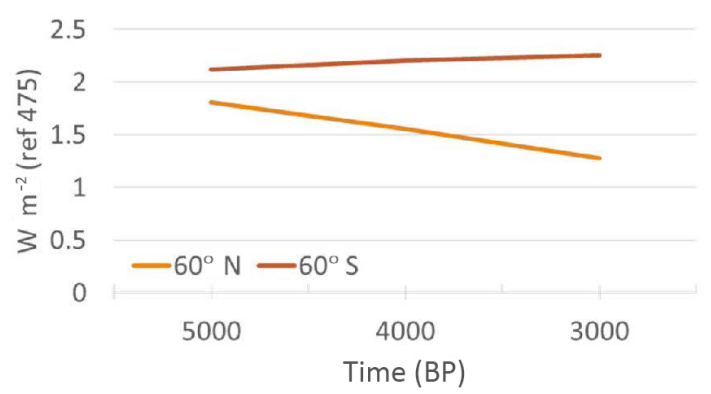

(b) Atmospheric $\mathrm{CO}_{2}$ concentration

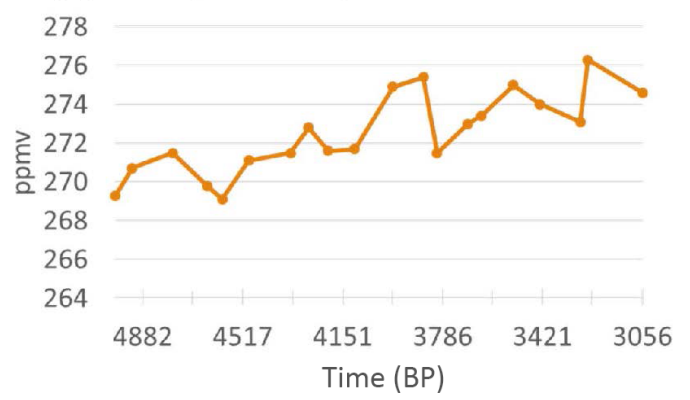

Figure 1. Time series of (a) transient summer insolation (at $60^{\circ} \mathrm{N}$ and $60^{\circ} \mathrm{S}$ ) changes resulting from the orbital variation and (b) the transient $\mathrm{CO}_{2}$ change used in the simulations.

The transient June insolation changes at $60^{\circ} \mathrm{N}$ and $60^{\circ} \mathrm{S}$ that resulted from the orbital variation and the transient $\mathrm{CO}_{2}$ change used in the simulations are shown in Fig. 1. The continental ice-sheet and topography changes are based on the ICE-5G (VM2) reconstruction (Peltier, 2004; He et al., 2013). For the geography changes, the Barents Sea opens at $13.1 \mathrm{ka}$, the Bering Strait opens at $12.9 \mathrm{ka}$, Hudson Bay opens at $7.6 \mathrm{ka}$ and the Indonesian throughflow opens at $6.2 \mathrm{ka}$. The freshwater injected into Northern Hemisphere (NH) and Southern Hemisphere (SH) oceans are based on specific time slices (e.g., 19 ka into North Atlantic, 17 ka into North Atlantic, 11.5 ka into Arctic, St. Lawrence River, Hudson Strait, Barents Sea, North Sea, Ross Sea and Weddell Sea). Note that no freshwater was delivered to the ocean after $5000 \mathrm{BP}$ in the TraCE-ALL and TraCE-MWF experiments. Detailed information about the experiment design can be found in $\mathrm{He}$ (2011) and He et al. (2013).

The TraCE-21ka simulation was evaluated with reconstructions and was found that it could reproduce major deglacial temperature evolutions (Clark et al., 2012; Shakun et al., 2012). It has been used to depict the causes and mechanisms of Holocene climate changes, such as the BøllingAllerød warming (Liu et al., 2009), cooling into the Younger Dryas and recovery to warm conditions (Liu et al., 2012), and the El Niño-Southern Oscillation (ENSO) evolution over the past $21 \mathrm{kyr}$ (Liu et al., 2014a). In the present work, we adopted the period of 5000-3000 BP to focus on the $4.2 \mathrm{ka} \mathrm{BP}$ event. (a)

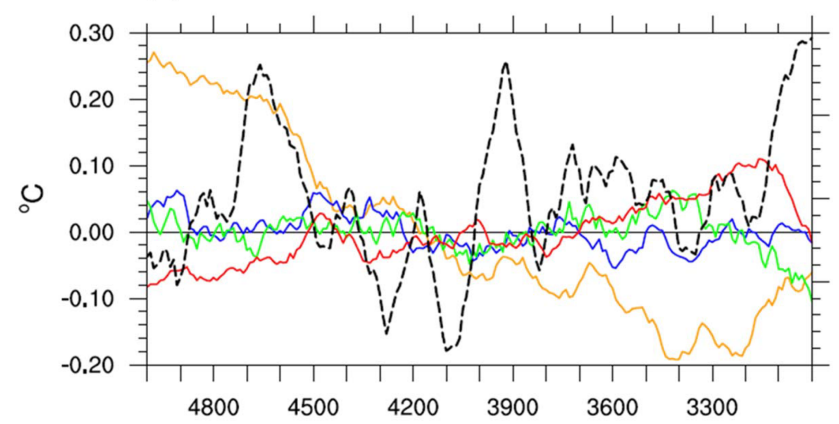

(b)

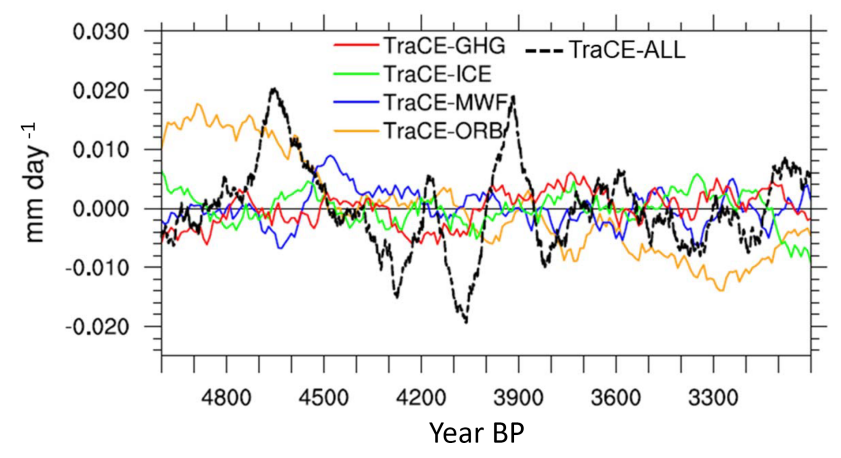

Figure 2. Time series of annual mean NH (a) surface temperature anomalies and (b) precipitation anomalies derived from the TraCEALL run (dashed black lines) and each single-forcing run (solid color lines) from 5 to $3 \mathrm{ka}$. A 101-year running mean has been applied to the time series.

\section{Results}

\subsection{Identification of $4.2 \mathrm{ka} \mathrm{BP}$ event in the model simulation}

The 101-year running mean annual NH surface temperature and precipitation during 5-3 ka shows double-peak centennial cooling and drought from 4.4 to $4.0 \mathrm{ka}$ (Fig. 2, dashed black line). However, the variabilities are smaller over the $\mathrm{SH}$ than those over the NH. There is no significant cooling and drought event during that period (Fig. S1 in the Supplement, dashed black line) over the SH. The SH precipitation even shows a double-peak wet condition during the period of $4.4-4.0 \mathrm{ka}$.

The double-peak centennial cooling and drought are still obvious when the 31-year running mean is applied to the time series (not shown), which indicates that the simulated climate events are potentially comparable to the $4.2 \mathrm{ka}$ event. Moreover, the centennial warming periods right before and after the cooling event indicate that this event might be included in a quasi-millennium variation. Therefore, the $4.2 \mathrm{ka} \mathrm{BP}$ event could be a multiscale event, i.e., from multi-decadal to millennium.

The seasonal mean NH surface temperature changes show that the annual mean variability is dominated by the boreal 
Table 1. The information of the experiments used in this study.

\begin{tabular}{llll}
\hline Experiments & Forcings & Time spanning & Temporal resolution \\
\hline TraCE-ALL & Orbital, meltwater flux, continental ice sheet and greenhouse gases & 22000 BP to 1990 CE & Monthly mean \\
TraCE-ORB & Orbital only & 22000 BP to 1990 CE & Decadal mean \\
TraCE-MWF & Meltwater flux only & 19000 BP to 1990 CE & Decadal mean \\
TraCE-ICE & Continental ice sheets only & 19000 BP to 1990 CE & Decadal mean \\
TraCE-GHG & Greenhouse gases only & 22 000 BP to 1990 CE & Decadal mean \\
\hline
\end{tabular}

winter (December-January-February, DJF) surface temperature change (Fig. S2). The correlation coefficient between the annual mean NH surface temperature (NHT) and the DJF mean NHT is 0.96 (after the 101-year running mean), which is significant above the $99 \%$ confidence level, much higher than the correlation coefficient between the annual mean and the boreal summer (June-July-August, JJA) mean of only 0.30 (after the 101-year running mean), which is not significant. However, this is different for the precipitation change, for which both the JJA mean and the DJF mean contribute to the annual mean precipitation change (not shown).

To identify the characteristics of the $4.2 \mathrm{kaBP}$ event, two centennial cool periods and two centennial warm periods that exceeded \pm 0.5 standard deviations are selected. The two centennial cool periods span from 4320 to $4220 \mathrm{BP}$ and from 4150 to $4050 \mathrm{BP}$, and the two centennial warm periods span from 4710 to $4610 \mathrm{BP}$ and from 3980 to $3880 \mathrm{BP}$.

\subsection{Spatial characteristics of surface temperature and precipitation}

To help draw a coherent global view of the $4.2 \mathrm{ka}$ BP event, the spatial characteristics of temperature and precipitation changes during the $4.2 \mathrm{ka}$ BP event are shown in Fig. 3.

Figure $3 \mathrm{a}$ gives the spatial distribution of the annual mean surface temperature difference between the cold periods and the warm periods. The cooling significantly occurred over most regions of the $\mathrm{NH}$, especially over the middle to high latitudes of the $\mathrm{NH}$ and most land regions of the SH. Most parts of India, northern Mexico and the middle latitudes of the SH ocean experienced warm conditions. Such asymmetric change between the hemispheres (cool $\mathrm{NH}$ and warm $\mathrm{SH}$ ) favors the southward shift of the ITCZ. The spatial distribution of the surface temperature change is still dominated by the boreal winter pattern (not shown). The large cooling over the $\mathrm{NH}$ and small warming over the SH could be related to the orbital change (Fig. S3), which induces insolation increasing over the $\mathrm{SH}$ but decreasing over the $\mathrm{NH}$.

The spatial distribution of annual mean precipitation differences between the cold periods and the warm periods is shown in Fig. 3b. During the cold periods, significant drought is mainly located over many land regions of the $\mathrm{NH}$, especially over Europe, western Asia, and interior North America and Central America. The significant dry conditions over the Dead Sea, the Gulf of Oman, interior North America (a) Annual mean TS

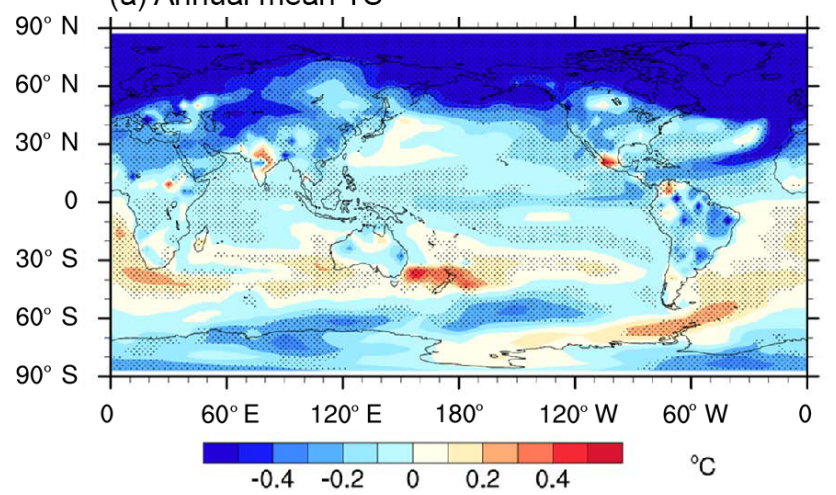

(b) Annual mean precip.

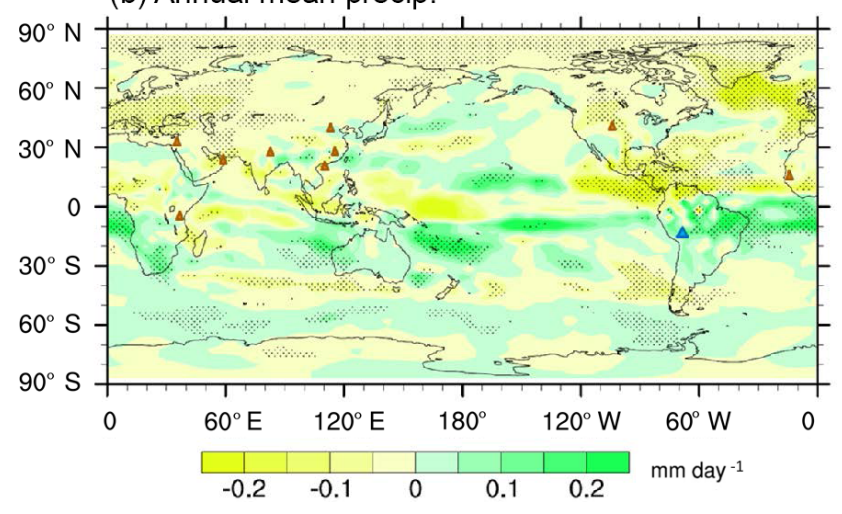

Figure 3. Spatial distribution of the annual mean (a) surface temperature (TS) and (b) precipitation differences between the cold periods and warm periods derived from the TraCE-ALL run. Those regions which were significant above the $95 \%$ confidence level are dotted. Triangles in (b) denote the dry (orange) and wet (blue) conditions documented in the records, including the following sites: Kilimanjaro ( $3^{\circ} 04.6^{\prime} \mathrm{S}, 37^{\circ} 21.2^{\prime} \mathrm{E}$ ) (Thompson et al., 2002), Dead Sea (Yechieli et al., 1993), Gulf of Oman $\left(24^{\circ} 23.4^{\prime} \mathrm{N}, 59^{\circ} 2.5^{\prime} \mathrm{E}\right)$ (Cullen et al., 2000), Lake Rara $\left(29^{\circ} 32^{\prime} \mathrm{N}, 82^{\circ} 05^{\prime} \mathrm{E}\right.$ ) (Nakamura et al., 2016), Maar Lake in Huguangyan $\left(21.15^{\circ} \mathrm{N}, 110.29^{\circ} \mathrm{E}\right.$ ) (Liu et al., 2000), Daihai Lake $\left(40.58^{\circ} \mathrm{N}, 112.7^{\circ} \mathrm{E}\right)$ (Peng et al., 2005), Poyang Lake $\left(29.15^{\circ} \mathrm{N}, 116.27^{\circ} \mathrm{E}\right)$ (Ma et al., 2004), eastern Colorado Dunes $\left(40^{\circ} 20^{\prime} \mathrm{N}, 104^{\circ} 16^{\prime} \mathrm{E}\right)$ (Forman et al., 1995), Lake Titicaca $\left(12.08^{\circ} \mathrm{S}, 69.85^{\circ} \mathrm{W}\right)$ and Lake Guiers $\left(16.3^{\circ} \mathrm{N}, 16.5^{\circ} \mathrm{W}\right)$ (Marchant and Hooghiemstra, 2004).

and western North Africa and the wet conditions over South America are consistent with the reconstructions (Yechieli et 
Annual mean SST diff between cold and warm periods SST (TraCE-ALL)

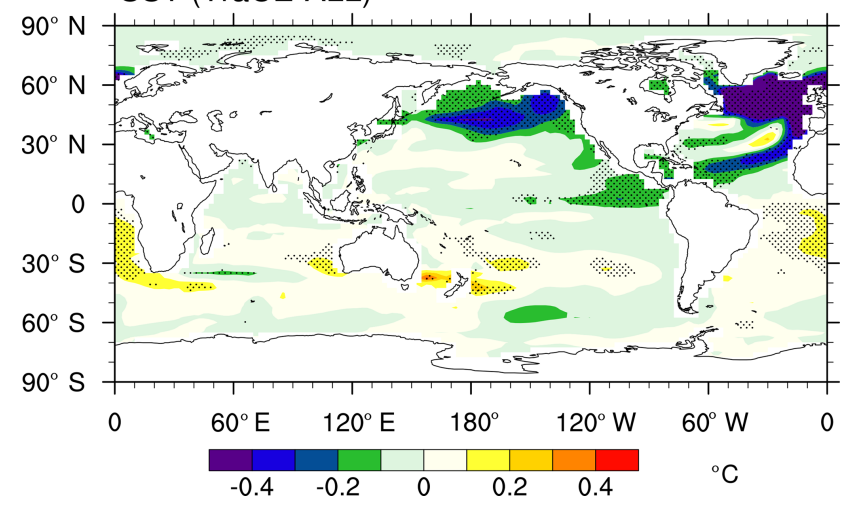

Figure 4. Spatial distribution of annual mean SST difference between the cold and warm periods derived from the TraCE-ALL run. Those regions which were significant above the $95 \%$ confidence level are dotted.

al., 1993; Forman et al., 1995; Cullen et al., 2000; Marchant and Hooghiemstra, 2004). For the SH, the land precipitation increased, which indicates a southward shift of the ITCZ, as suggested by the aforementioned asymmetric temperature change and by the previous studies based on both reconstructions (Fleitmann et al., 2007; Cai et al., 2012) and simulations (Broccoli et al., 2006). Over East China, the precipitation anomalies show a wet-south-dry-north pattern, which indicates a weakened East Asian monsoon revealed by the reconstruction record (Tan et al., 2018). However, the simulated anomaly pattern is not very significant over East China. This might be related to the model resolution, the model performance or the actual climate change. Therefore, simulations with higher resolution, inter-model and model-data comparisons are required to gain a clearer view about the climate change over East China.

The sea surface temperature (SST) shows that the largest change occurs over the northern Atlantic Ocean and then the northern Pacific Ocean (Fig. 4). The warmer south and cooler north over the Atlantic Ocean indicates an Atlantic MultiDecadal Oscillation (AMO)-like pattern with its cold phase. The cold phase of the AMO has been confirmed to induce summer rainfall decreases over India and Sahel in both simulations and proxy data (Zhang and Delworth, 2006; Shanahan et al., 2009).

The simulated characteristics of the temperature change, the precipitation change and the SST change are similar to those responses to the weakened AMOC state (Vellinga and Wood, 2002; Zhang and Delworth, 2005; Delworth and Zeng, 2012; Brown and Galbraith, 2016) (Fig. S4).

\subsection{Circulations associated with the $4.2 \mathrm{ka} \mathrm{BP}$ event}

The sea level pressure (SLP) differences between the cooler periods and the warmer periods show that the largest change occurs over the mid- to high latitudes of the $\mathrm{NH}$ and $\mathrm{SH}$ (Fig. 5a). The negative SLP anomalies over the high North Atlantic and positive SLP anomalies over the middle North Atlantic during the cool periods resemble a positive North Atlantic Oscillation (NAO)-like pattern but on a centennialmillennial timescale. The positive NAO-like pattern is accompanied by cyclonic circulation over Iceland and anticyclonic circulation over the Azores and thus strengthened westerlies over the downstream regions (Fig. 5a). The subtropical highs and the relative anticyclones in both the $\mathrm{SH}$ and $\mathrm{NH}$ are strengthened during the cold periods from low troposphere $(850 \mathrm{hPa})$ to high troposphere $(200 \mathrm{hPa})$, which illustrates a barotropic structure (Fig. 5). Note that the strengthened subtropical highs over the $\mathrm{NH}$ are most significant at a low level (sea level and $850 \mathrm{hPa}$ ), while the subtropical highs over the $\mathrm{SH}$ are most significant at a high level $(200 \mathrm{hPa})$. The centers with positive geopotential height anomalies during the $4.2 \mathrm{ka} \mathrm{BP}$ event over western Europe, Central Asia, East Asia, the east North Pacific and eastern North America, as well as the anticyclonic circulation anomalies at $200 \mathrm{hPa}$ (Fig. 5d), resemble a circumglobal teleconnection (CGT)-like wave pattern (Ding and Wang, 2005; Lin et al., 2016) but on a centennial-millennial timescale.

The strengthened subtropical highs with midlatitude anticyclones from lower to upper levels are the direct physical processes that cause the precipitation decreases and thus the following mega-drought over midlatitudes of NH regions, particularly over Eurasia. The cooler- land-warmer-ocean over East Asia and the west Pacific (Fig. 3a) indicates a weakened land-ocean thermal contrast associated with significantly higher SLP over land and lower SLP over the adjacent ocean (insignificant) (Fig. 5a). The weakened landocean contrast can lead to a weaker East Asian monsoon, accompanied by precipitation increases over the southern China pattern and precipitation decreases over the northern China pattern (Fig. 3b). Such a conclusion is very rough, since the simulated anomaly patterns are not very significant. More investigations with higher resolutions of modeling and reconstruction work are required to get satisfactory results.

\section{Discussions}

The simulations show that the cool and dry conditions of the $4.2 \mathrm{kaBP}$ event are more like a hemispheric phenomenon, mainly located over the $\mathrm{NH}$ rather than a global phenomenon. The land over the SH experiences cool but wet conditions, and the midlatitude SH ocean is warmer. The potential causes and mechanisms of this event will be discussed in this section. 
(a) SLP \& $850 \mathrm{hPa}$ wind

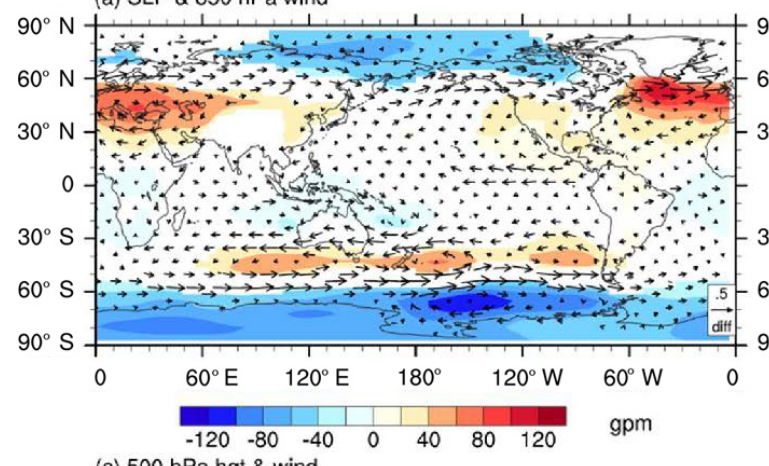
(c) $500 \mathrm{hPa}$ hgt \& wind

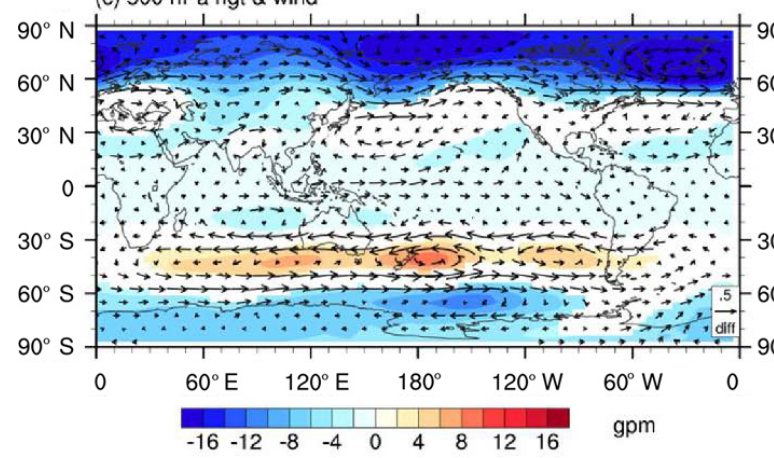

(b) $850 \mathrm{hPa}$ hgt $\&$ wind

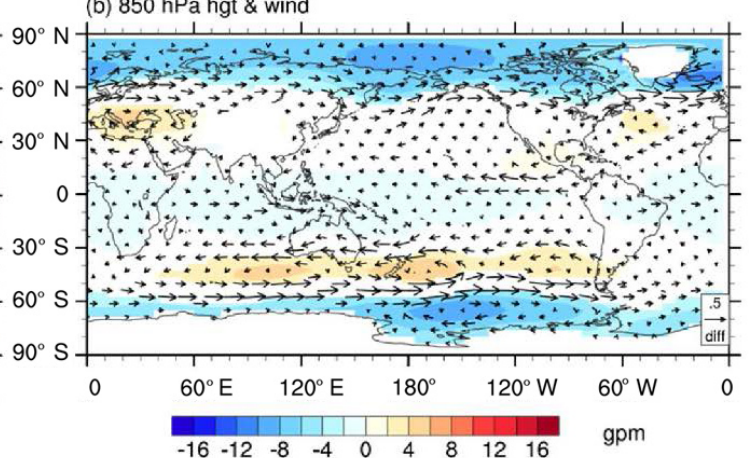

(d) $200 \mathrm{hPa}$ hgt \& wind

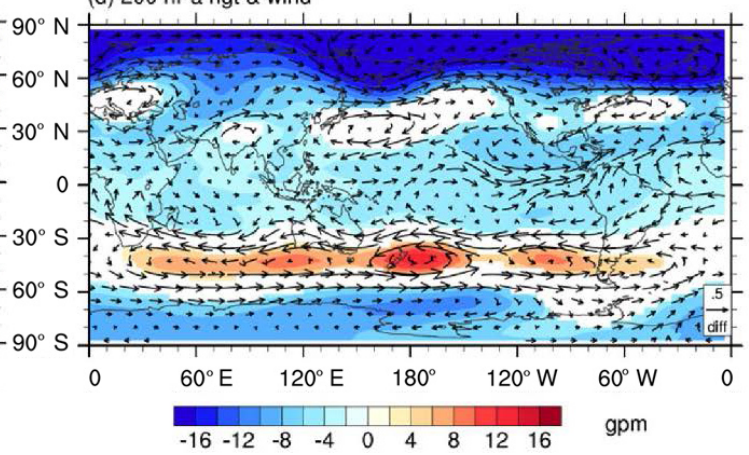

Figure 5. Differences in annual mean (a) sea level pressure and $850 \mathrm{hPa}$ wind, (b) geopotential height and wind at $850 \mathrm{hPa}$, (c) geopotential height and wind at $500 \mathrm{hPa}$, and (d) geopotential height and wind at $200 \mathrm{hPa}$ between cold and warm periods derived from the TraCE-ALL run. Those regions which were significant above the $95 \%$ confidence level are plotted.

\subsection{The possible causes of the $4.2 \mathrm{kaBP}$ event}

Some records suggested that solar irradiance was one of the essential mechanisms that drove the Holocene climate variation at centennial to millennial timescales (Bond et al., 2001), whereas others suggested that the link between solar irradiance and multi-century-scale cooling events during the Holocene was weak, particularly in the Middle to Late Holocene (Turney et al., 2005; Wanner et al., 2008). Changes in solar irradiance are not included in the experiments used in the present work. Nonetheless, we still obtain multi-century cooling events (such as the $4.2 \mathrm{kaBP}$ event) in the TraCEALL experiment but with smaller magnitude. This side fact indicates that the solar irradiance might not be the driving factor for the Holocene cooling events.

If the results derived from the TraCE-ALL experiment are consistent with those derived from a particular single-forcing sensitivity experiment, we assume the variation to be forced by that forcing. Otherwise, if the results derived from the TraCE-ALL experiment differ from those from the singleforcing sensitivity experiments, we assume the variation to be forced by internal variability. In this section, we use the series after applications of 101-year running means as an example and compare the results derived from the all-forcing experiment to those derived from the single-forcing exper-
Table 2. Correlation coefficients between the annual mean and seasonal mean NHTs derived from the TraCE-ALL run and those from each single-forcing run from 5.0 to $3.0 \mathrm{ka}$.

\begin{tabular}{lrrr}
\hline Single-forcing run & Annual mean & JJA mean & DJF mean \\
\hline TraCE-ORB & -0.05 & 0.79 & -0.12 \\
TraCE-MWF & -0.18 & 0.48 & -0.43 \\
TraCE-ICE & -0.30 & -0.20 & -0.18 \\
TraCE-GHG & 0.14 & -0.73 & 0.40 \\
\hline
\end{tabular}

iment to determine the possible forcings that triggered the $4.2 \mathrm{ka}$ BP event.

The correlation coefficients between the annual mean NHT derived from the TraCE-ALL run and the NHT derived from each single-forcing run are listed in Table 2. A two-sided Student's $t$ test is used for the statistical significance test, assuming 20 degrees of freedom, which is estimated simply from a 2000-year time series subjected to a 100-year running mean (Delworth and Zeng, 2012). There is no significant clue that the annual mean NHT variation is forced by the orbital variation or the other forcings due to the nonsignificant correlations. During the period of 5000$3000 \mathrm{BP}$, the variation in simulated JJA mean NHT is likely forced by the solar radiation due to the orbital variation (Table 2; the correlation coefficient between the two series is 
0.79 at $p<0.05$ ), whereas the greenhouse gas change has a comparable negative impact on the JJA mean NHT (the correlation coefficient is -0.73 at $p<0.05)$. The meltwater flux also has a moderate contribution to the JJA mean NHT change (the correlation coefficient is 0.48 at $p<0.05$ ). For the DJF mean NHT, only meltwater flux has a notable negative effect (the correlation coefficient is -0.43 at $p<0.05$ ). However, there is no meltwater forcing during this period, so the NHT change can be taken as internal variability. Therefore, the significant correlation coefficient between the allforcing run result and the meltwater forcing run result might be a coincidence, due to the autocorrelation of internal variability. This is another side fact indicating the cold events during the Late Holocene might be related to internal variability. Note that if the effective degree of freedom is used, none of the abovementioned correlation coefficients are significant. The effective degree of freedom is calculated by the following equation:

$N_{\mathrm{dof}}=N \times \frac{1-r_{1} \times r_{2}}{1+r_{1} \times r_{2}}$,

where $N_{\text {dof }}$ is the effective degree of freedom regarding the two correlation samples, $N$ is the total sample size, and $r_{1}$ and $r_{2}$ are autocorrelation lag- 1 values for sample 1 and sample 2, respectively (Bretherton et al., 1999).

On the other hand, the annual mean NHT difference between the TraCE-ALL run and the sum of the four singleforcing sensitivity experiments shows variation similar to the NHT derived from the TraCE-ALL run from 5000 to 3000 BP (Fig. S5). The correlation coefficient between these two time series is 0.66 , which is significant above the $95 \%$ confidence level (assuming 20 degrees of freedom). We assume the difference between the TraCE-ALL run and the sum of the four single-forcing runs to be the internal variation, assuming that the climate responses to external forcings are linear at global and hemispheric scales. Therefore, the internal variation might play a dominant role in the climatic variation during the period of 5000-3000 BP. However, the linearity of the climate responding to external forcings needs further clarification, since there would be interactions between each forcing and between forcings and internal variability.

Moreover, there is no double-peak cooling event during the period of 4400-4000 BP in any single-forcing run (Fig. 1, colored lines), which indicates that the $4.2 \mathrm{ka} \mathrm{BP}$ event might not be triggered by those external forcings, including orbital forcing, the meltwater flux, the ice sheets and the greenhouse gases in isolation. Volcanic eruptions have been identified as one of the important drivers of climate variation, whereas there were few eruptions during 4400-4000 BP (Sigl et al., 2018). Therefore, we conclude that the variability relating to the $4.2 \mathrm{kaBP}$ event might be driven by internal variability. Klus et al. (2018) also suggested that the internal climate variability could trigger abrupt cold events in the North At- lantic without external forcings (e.g., solar irradiance or volcanic).

However, why such large variation due to internal variability occurs at approximately $4.2 \mathrm{ka}$ BP remains unknown. There is little ice-sheet change and no meltwater discharge after $5.0 \mathrm{ka}$ in the TraCE-ICE run and TraCE-MWF run, and the variations in climate derived from these two runs can thus be regarded as internal variabilities. The multi-centennial cooling events can also be found in the standardized NHT during the last 5000 years of the two experiments (Fig. S6), and there are drought events in the standardized $\mathrm{NH}$ precipitation time series (not shown). However, the timing of those cooling and drought events occurs stochastically. This indicates a general concept of the random variation in the internal mode of the climate system. There is a reduction in $\mathrm{NH}$ temperature and precipitation at around $4600 \mathrm{BP}$ in the TraCE-ORB (Fig. 2, orange lines), which might be related to the timing of the event as speculated by Ning et al. (2019).

Ning et al. (2019) compared the fifth millennium BP cooling with the ninth millennium cooling and concluded that the ninth millennium BP cooling resulted from freshwater forcing while orbital forcing is the most likely explanation of cooling in the North Atlantic starting from the early fifth millennium BP through most of the later Holocene but with fluctuations. In the present work, we attribute this fluctuation to internal variability, which is superposed on the orbitally induced long-term trend. This work and Ning et al.'s (2019) work focus on different aspects and different timescales, and they are complementary to better understand the $4.2 \mathrm{kaBP}$ event.

\subsection{The mechanisms of the centennial-millennial cooling and drought}

As has been mentioned in Sect. 3.3, the low-level NAO-like pattern and upper-level CGT-like pattern are the direct mechanisms that cause cooling and mega-droughts over most parts of the NH. Previous studies also proposed that the temperature and precipitation changes over Eurasia and Africa were directly linked to the NAO (Cullen et al., 2002; Kushnir and Stein, 2010). The first leading mode of the empirical orthogonal function (EOF) of the annual mean SLP during 5-3 ka shows a double-peak positive NAO-like pattern but on a centennial scale during the period of 4400-4000 BP (Fig. 6). The first leading EOF of geopotential height at $200 \mathrm{hPa}$ after the application of a 31-year running mean shows a CGT-like pattern and similar double-peak variation during the period of 4400-4000 BP, which is more obvious after applying the 101-year running mean (Fig. 7). This means that the doublepeak cooling and drought of the $4.2 \mathrm{kaBP}$ event could be strongly related to the double-peak positive NAO-like pattern (at a low level) and CGT-like pattern (at a high level) at a centennial timescale.

$\mathrm{Li}$ et al. (2013) suggested that the NAO is a predictor of NHT multi-decadal variability during the 20th century. In 

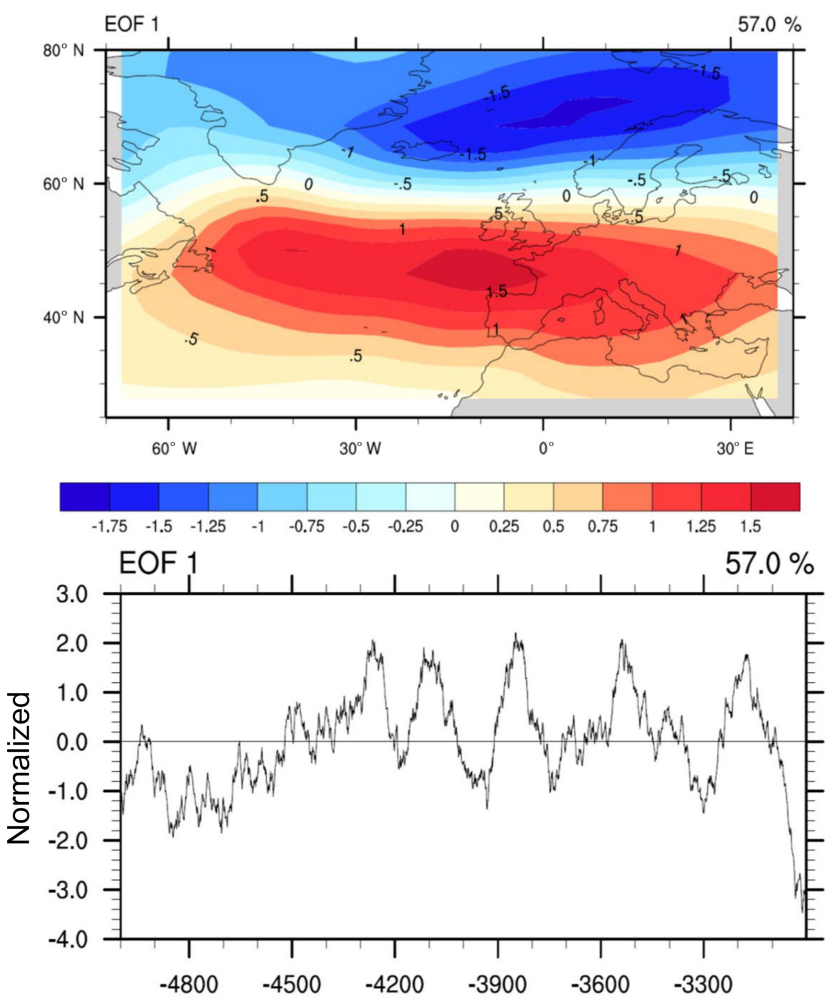

Figure 6. Standardized first leading mode of the EOF of annual mean SLP over the North Atlantic region $\left(25-80^{\circ} \mathrm{N}, 70^{\circ} \mathrm{W}-40^{\circ} \mathrm{E}\right)$ during the period of 5.0 to $3.0 \mathrm{ka}$ derived from the TraCE-ALL run, after the application of a 101-year running mean. The spatial distribution is shown in the top panel, and the time series is shown in the bottom panel. Only this mode passed the North test for the EOF.

this study, significant correlation is also found between the annual mean NAO index and the annual mean NHT during the period of $4400-4000 \mathrm{BP}$, with the NAO leading by approximately 40 years (Fig. 8). The NAO index is defined by the first leading mode of the EOF of the SLP. The regressed annual mean surface temperature against the NAO index 40 years earlier during 4400 and $4000 \mathrm{BP}$ shows cooler NH high latitudes and a warmer SH (Fig. S7), especially the cooling over the northern North Atlantic Ocean, Europe, East Asia and North America.

The geopotential height at $200 \mathrm{hPa}$ regressed against the SST over the two North Atlantic outstanding regions (Fig. 4) shows a CGT-like pattern after the application of a 31-year running mean (Fig. 9), which is similar to the conclusion from Lin et al. (2016) that the CGT could be excited by the AMO-related SST anomaly. The regressed $200 \mathrm{hPa}$ geopotential height shows a similar pattern after the application of a 101-year running mean (not shown). The anticyclones associated with a CGT-like pattern over western Europe, Central Asia and North America can suppress the precipitation and thus lead to mega-drought over these regions.
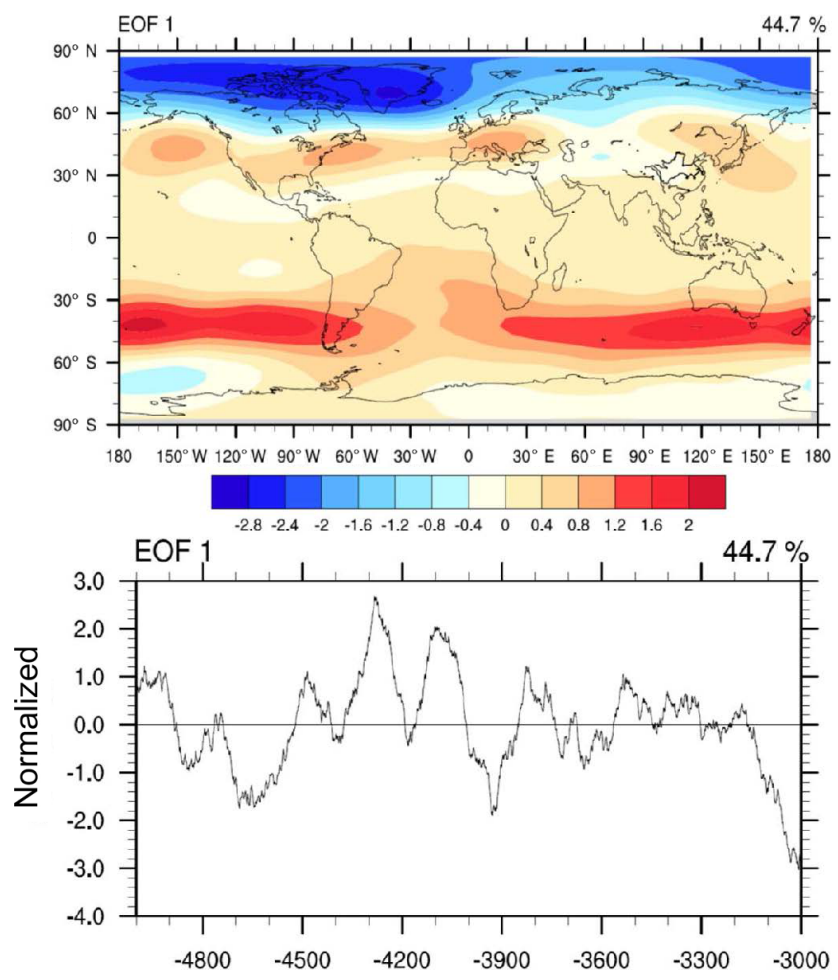

Figure 7. Standardized first leading mode of the EOF of annual mean geopotential height at $200 \mathrm{hPa}$ during the period of 5.0 to $3.0 \mathrm{ka}$ derived from the TraCE-ALL run, after the application of a 101-year running mean. The spatial distribution is shown in the top panel, and the time series is shown in the bottom panel. Only this mode passed the North test for the EOF.

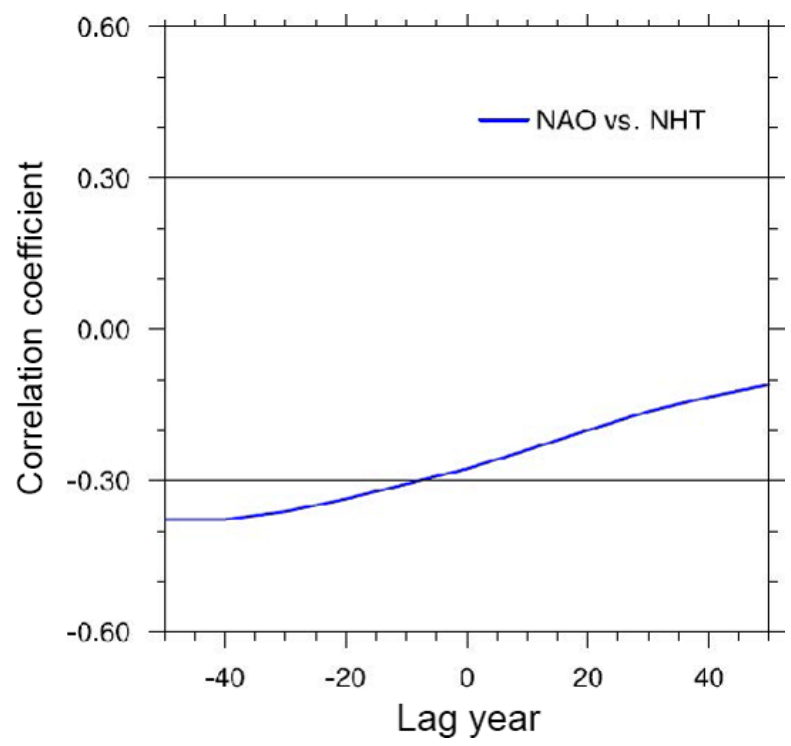

Figure 8. Lead-lag correlation between the annual mean North Atlantic Oscillation (NAO) and the Northern Hemisphere surface temperature (NHT) during 4.4-4.0 ka derived from the TraCE-ALL run. The black lines $( \pm 0.3)$ show the significance levels $(p<0.05)$. 


\section{hgt200 regressed on SST_north atlantic two (ANN)}
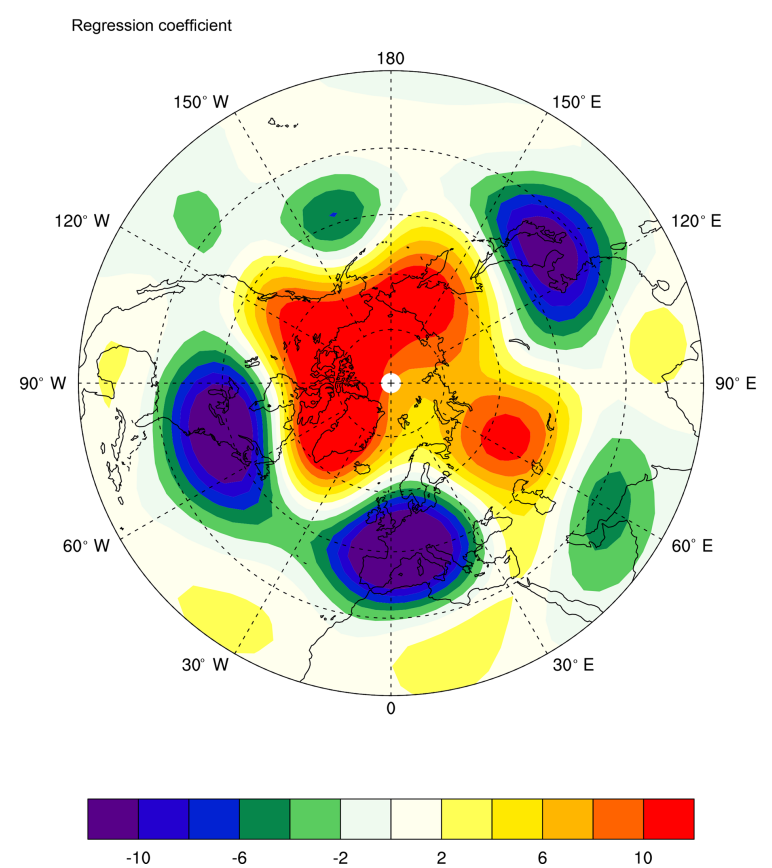

Figure 9. Annual mean geopotential height regressed against the SST over the North Atlantic during 5.0-3.0 ka derived from the TraCE-ALL run, after 31-year running mean application.

Considering the NAO-like pattern, the CGT-like pattern and the AMO-like pattern together, we suggest that the AMO could be playing a "bridge" role to keep the barotropic structure at the centennial scale, which is similar to the synthesis proposed by $\mathrm{Li}$ et al. (2013) that the AMO is a bridge that links the NAO and NHT at a multi-decadal timescale. Delworth and Zeng (2016) suggested that the NAO variation had a significant impact on the AMOC and its subsequent influence on the atmosphere and large-scale climate at multi-decadal-centennial timescales. Other studies also focused on the role of SST anomalies over the North Pacific and North Atlantic oceans when investigating the possible mechanisms of the $4.2 \mathrm{ka} \mathrm{BP}$ event (Kim et al., 2004; Marchant and Hooghiemstra, 2004; Booth et al., 2005).

We note the centennial-millennial variation in the AMOC after the mid-Holocene in the all-forcing run (Fig. S4a). There also exits a double-peak variation during the period of $4.4-4.0 \mathrm{ka}$, accompanied by similar spatial patterns of temperature and precipitation anomalies as in the simulated $4.2 \mathrm{ka} \mathrm{BP}$ event (Fig. S4b, c). However, whether this AMOC variation is related to external forcing, such as orbital forcing, or just internal variability remains unknown and needs further investigations.

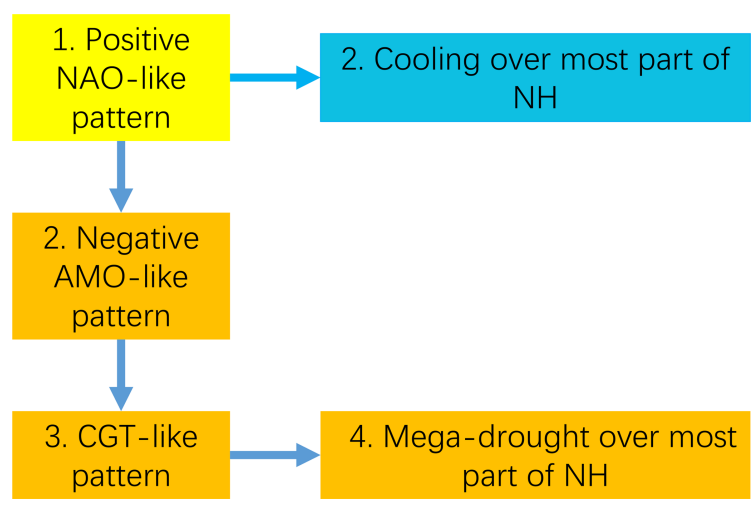

Figure 10. Schematic diagram showing the mechanisms behind the $4.2 \mathrm{ka} \mathrm{BP}$ event.

\section{Conclusion}

The characteristics of the $4.2 \mathrm{ka} \mathrm{BP}$ event along with the potential drivers and the mechanisms are investigated using a set of transient climate simulations. The simulated event is characterized by hemispheric cooling and mega-drought over the $\mathrm{NH}$, whereas the $\mathrm{SH}$ experiences warming (over the midlatitude ocean) and wet conditions during this event. The annual mean temperature change is dominated by the boreal winter change. The cool and dry $\mathrm{NH}$ and warm and wet $\mathrm{SH}$ pattern indicate a southward shift of the ITCZ, as suggested by the reconstructions. These characteristics could also be related to a weakening of the AMOC, which needs further investigation.

By comparison between the all-forcing experiment and the single-forcing sensitivity experiments, the $4.2 \mathrm{kaBP}$ event can largely be attributed to internal variability, although orbital forcing and greenhouse gases could impact the boreal summer NHT variation. The origin could be in polar regions and the North Atlantic and may influence the NH climate through teleconnections such as the NAO-like pattern and the CGT-like pattern. The positive NAO-like pattern in the atmosphere triggers cooling over the $\mathrm{NH}$ and the negative AMO-like pattern in the ocean, which may last for decades or even centuries. The negative AMO-like pattern triggers CGTlike wave patterns at a multi-decadal-centennial timescale accompanied by anticyclones over western Europe, Central Asia and North America, which induce mega-drought over those regions. The simplified diagram of the mechanism is shown in Fig. 10.

Our findings provide a global pattern and mechanical background of the $4.2 \mathrm{kaBP}$ event that can help better understanding this event. We consider the internal variabilities to be an essential forcing of the $4.2 \mathrm{kaBP}$ event. However, whether or not external forcings have modulation effects needs to be clarified. For example, is the timing of the event stochastic due to internal variability or modulated by external forcings such as orbital changes? Why the SST forcing 
in the North Atlantic can be maintained at a multi-decadalcentennial timescale requires more study. Current results are mainly based on annual mean precipitation and temperature, whereas the impacts of external forcings may have seasonal dependence; further investigations are required to evaluate these impacts.

The model responses to external forcings are small, especially in the Holocene, because of the absence of a significant change in the AMOC and meltwater forcing after $6 \mathrm{ka}$ (Liu et al., 2014b). So we use the amplified anomalies between the cold and warm periods, rather than simply the cold anomalies against the long-term average, to illustrate the mechanisms of the event. We need to keep in mind that we still might not be modeling events comparable to the $4.2 \mathrm{ka} \mathrm{BP}$ event, particularly during the Late Holocene. More modeldata, inter-model and inter-event comparisons are required to better understand the cold events during the Holocene.

Data availability. The TraCE-21ka data used in this study can be accessed through the website of Earth System Grid (2018) (https: //www.earthsystemgrid.org/project/trace.html, last access: 1 June 2018).

Supplement. The supplement related to this article is available online at: https://doi.org/10.5194/cp-15-265-2019-supplement.

Author contributions. MY and JL designed the work. MY performed the formal analyses and prepared the paper. JL provided supervision.

Competing interests. The authors declare that they have no conflict of interest.

Special issue statement. This article is part of the special issue "The 4.2 ka BP climatic event". It is a result of "The $4.2 \mathrm{ka}$ BP Event: An International Workshop", Pisa, Italy, 10-12 January 2018.

Acknowledgements. We acknowledge Bin Wang and two anonymous referees for the comments helping to clarify and improve the paper. This research was jointly supported by the $\mathrm{Na}-$ tional Key Research and Development Program of China (grant no. 2016YFA0600401), the National Basic Research Program (grant no. 2015CB953804), the National Natural Science Foundation of China (grant nos. 41671197, 41420104002 and 41631175), Open Funds of State Key Laboratory of Loess and Quaternary Geology, Institute of Earth Environment, CAS (SKLLQG1820), and the Priority Academic Development Program of Jiangsu Higher Education Institutions (PAPD, grant no. 164320H116). TraCE-21ka was made possible by the DOE INCITE computing program and supported by NCAR, the NSFP2C 2 program and the
DOE Abrupt Change and EaSM programs.

Edited by: Monica Bini

Reviewed by: two anonymous referees

\section{References}

Alley, R. and Agustsdottir, A.: The 8k event: cause and consequences of a major Holocene abrupt climate change, Quaternary Sci. Rev., 24, 1123-1149, https://doi.org/10.1016/j.quascirev.2004.12.004, 2005.

An, C.-B., Tang, L., Barton, L., and Chen, F.-H.: Climate change and cultural response around $4000 \mathrm{calyr} \mathrm{BP}$ in the western part of Chinese Loess Plateau, Quaternary Res., 63, 347-352, https://doi.org/10.1016/j.yqres.2005.02.004, 2005.

Bond, G., Kromer, B., Beer, J., Muscheler, R., Evans, M. N., Showers, W., Hoffmann, S., Lotti-Bond, R., Hajdas, I., and Bonani, G.: Persistent solar influence on North Atlantic climate during the Holocene, Science, 294, 2130-2136, 2001.

Booth, R. K., Jackson, S. T., Forman, S. L., Kutzbach, J. E., Bettis, I. E. A., Kreig, J., and Wright, D. K.: A severe centennial-scale drought in mid-continental North America 4200 years ago and apparent global linkages, Holocene, 15, 321-328, 2005.

Bretherton, C. S., Widmann, M., Dymnikov, V. P., Wallace, J. M., and Bladé, I.: The effective number of spatial degrees of freedom of a time-varying field, J. Climate, 12, 1990-2009, 1999.

Broccoli, A. J., Dahl, K. A., and Stouffer, R. J.: Response of the ITCZ to Northern Hemisphere cooling, Geophys. Res. Lett., 33, L01702, https://doi.org/10.1029/2005gl024546, 2006.

Brown, N. and Galbraith, E. D.: Hosed vs. unhosed: interruptions of the Atlantic Meridional Overturning Circulation in a global coupled model, with and without freshwater forcing, Clim. Past, 12, 1663-1679, https://doi.org/10.5194/cp-12-1663-2016, 2016.

Cai, Y., Zhang, H., Cheng, H., An, Z., Lawrence Edwards, R., Wang, X., Tan, L., Liang, F., Wang, J., and Kelly, M.: The Holocene Indian monsoon variability over the southern Tibetan Plateau and its teleconnections, Earth Planet. Sc. Lett., 335-336, 135-144, https://doi.org/10.1016/j.eps1.2012.04.035, 2012.

Clark, P. U., Shakun, J. D., Baker, P. A., Bartlein, P. J., Brewer, S., Brook, E., Carlson, A. E., Cheng, H., Kaufman, D. S., Liu, Z., Marchitto, T. M., Mix, A. C., Morrill, C., OttoBliesner, B. L., Pahnke, K., Russell, J. M., Whitlock, C., Adkins, J. F., Blois, J. L., Clark, J., Colman, S. M., Curry, W. B., Flower, B. P., He, F., Johnson, T. C., Lynch-Stieglitz, J., Markgraf, V., McManus, J., Mitrovica, J. X., Moreno, P. I., and Williams, J. W.: Global climate evolution during the last deglaciation, P. Natl. Acad. Sci. USA, 109, 1134-1142, https://doi.org/10.1073/pnas.1116619109, 2012.

Cullen, H., deMenocal, P., Hemming, S., Hemming, G., Brown, F. H., Guilderson, T., and Sirocko, F.: Climate change and the collapse of the Akkadian empire: Evidence from the deep sea, Geology, 28, 379-382, 2000.

Cullen, H. M., Kaplan, A., Arkin, P. A., and DeMenocal, P. B.: Impact of the North Atlantic Oscillation on Middle Eastern climate and streamflow, Clim. Change, 55, 315-338, 2002.

Deininger, M., McDermott, F., Mudelsee, M., Werner, M., Frank, N., and Mangini, A.: Coherency of late Holocene European speleothem $\delta^{18}$ records linked to North At- 
lantic Ocean circulation, Clim. Dynam., 49, 595-618, https://doi.org/10.1007/s00382-016-3360-8, 2017.

Delworth, T. L. and Zeng, F.: Multicentennial variability of the Atlantic meridional overturning circulation and its climatic influence in a 4000 year simulation of the GFDL CM2.1 climate model, Geophys. Res. Lett., 39, L13702, https://doi.org/10.1029/2012gl052107, 2012.

Delworth, T. L. and Zeng, F.: The Impact of the North Atlantic Oscillation on Climate through Its Influence on the Atlantic Meridional Overturning Circulation, J. Climate, 29, 941-962, https://doi.org/10.1175/jcli-d-15-0396.1, 2016.

Ding, Q. and Wang, B.: Circumglobal Teleconnection in the Northern Hemisphere summer, J. Climate, 18, 3483-3505, 2005.

Earth System Grid: TraCE-21ka data, available at: https://www. earthsystemgrid.org/project/trace.html, last access: 1 June 2018.

Finkenbinder, M. S., Abbott, M. B., and Steinman, B. A.: Holocene climate change in Newfoundland reconstructed using oxygen isotope analysis of lake sediment cores, Global Planet. Change, 143, 251-261, https://doi.org/10.1016/j.gloplacha.2016.06.014, 2016.

Fleitmann, D., Burns, S. J., Mangini, A., Mudelsee, M., Kramers, J., Villa, I., Neff, U., Al-Subbary, A. A., Buettner, A., Hippler, D., and Matter, A.: Holocene ITCZ and Indian monsoon dynamics recorded in stalagmites from Oman and Yemen (Socotra), Quaternary Sci. Rev., 26, 170-188, https://doi.org/10.1016/j.quascirev.2006.04.012, 2007.

Forman, S., Oglesby, R., Markgraf, V., and Stafford, T.: Paleoclimatic significance of Late Quaternary eolian deposition on the Piedmont and High Plains, Central United States, Global Planet. Change, 11, 35-55, 1995.

He, F.: Simulating Transient Climate Evolution of the Last deglaciation with CCSM3, Doctor of Philosophy, Atmospheric and Oceanic Sciences, University of Wisconsin-Madison, Wi, USA, 161 pp., 2011.

He, F., Shakun, J. D., Clark, P. U., Carlson, A. E., Liu, Z., OttoBliesner, B. L., and Kutzbach, J. E.: Northern Hemisphere forcing of Southern Hemisphere climate during the last deglaciation, Nature, 494, 81-85, https://doi.org/10.1038/nature11822, 2013.

Huang, C. C., Pang, J., Zha, X., Su, H., and Jia, Y.: Extraordinary floods related to the climatic event at $4200 \mathrm{aBP}$ on the Qishuihe River, middle reaches of the Yellow River, China, Quaternary Sci. Rev., 30, 460-468, https://doi.org/10.1016/j.quascirev.2010.12.007, 2011.

Jansen, E., Overpeck, J. T., Briffa, K. R., Duplessy, J.-C., Joos, F., Masson-Delmotte, V., Olago, D., Otto-Bliesner, B., Peltier, W. R., Rahmstorf, S., Ramesh, R., Raynaud, D., Rind, D. H., Solomina, O., Villalba, R., and Zhang, D.: Palaeoclimate, in: Climate Change 2007: The Physical Science Basis, Cambridge University Press, Cambridge, UK and New York, NY, USA, 2007.

Kim, J.-H., Rimbu, N., Lorenz, S. J., Lohmann, G., Nam, S.I., Schouten, S., Rühlemann, C., and Schneider, R. R.: North Pacific and North Atlantic sea-surface temperature variability during the Holocene, Quaternary Sci. Rev., 23, 2141-2154, https://doi.org/10.1016/j.quascirev.2004.08.010, 2004.

Klus, A., Prange, M., Varma, V., Tremblay, L. B., and Schulz, M.: Abrupt cold events in the North Atlantic Ocean in a transient Holocene simulation, Clim. Past, 14, 1165-1178, https://doi.org/10.5194/cp-14-1165-2018, 2018.
Kushnir, Y. and Stein, M.: North Atlantic influence on 19th20th century rainfall in the Dead Sea watershed, teleconnections with the Sahel, and implication for Holocene climate fluctuations, Quaternary Sci. Rev., 29, 3843-3860, https://doi.org/10.1016/j.quascirev.2010.09.004, 2010.

Lauritzen, S.-E.: Reconstruction of Holocene climate records from speleothems, in: Global Change in the Holocene, edited by: Mackay, A., Battarbee, R., Birks, H. J. B., and Oldfield, F., Arnold, London, UK, 242-263, 2003.

Li, J., Sun, C., and Jin, F.-F.: NAO implicated as a predictor of Northern Hemisphere mean temperature multidecadal variability, Geophys. Res. Lett., 40, 5497-5502, https://doi.org/10.1002/2013gl057877, 2013.

Lin, J.-S., Wu, B., and Zhou, T.-J.: Is the interdecadal circumglobal teleconnection pattern excited by the Atlantic multidecadal Oscillation?, Atmos. Ocean. Sci. Lett., 9, 451-457, https://doi.org/10.1080/16742834.2016.1233800, 2016.

Liu, J. Q., Lv, H. Y., Negendank, J. F. W., Mingram, J., Luo, X. J., Wang, W. Y., and Chu, G. Q: Cyclic of the Holocene climate variability in Huguangyan Maar lake, China, Chinese Sci. Bull., 45, 1190-1195, 2000 (in Chinese).

Liu, Y. H., Sun, X., and Guo, C. Q.: Records of $4.2 \mathrm{kaBP}$ Holocene Event from China and Its Impact on Ancient Civilizations, Geological Science and Technology Information (in Chinese), 32, 99-106, 2013.

Liu, Z. Y., Otto-Bliesner, B., He, F., Brady, E. C., Tomas, R. A., Clark, P. U., Carlson, A. E., Lynch-Stieglitz, J., Curry, W., Brook, E., Erickson, D. J., Jacob, R., Kutzbach, J., and Cheng, J.: Transient simulation of Last Deglaciation with a new mechanism for Bolling-Allerod Warming, Science, 325, 310-314, 2009.

Liu, Z., Carlson, A. E., He, F., Brady, E. C., Otto-Bliesner, B. L., Briegleb, B. P., Wehrenberg, M., Clark, P. U., Wu, S., Cheng, J., Zhang, J., Noone, D., and Zhu, J.: Younger Dryas cooling and the Greenland climate response to $\mathrm{CO}_{2}$, P. Natl. Acad. Sci. USA, 109, 11101-11104, https://doi.org/10.1073/pnas.1202183109, 2012.

Liu, Z., Lu, Z., Wen, X., Otto-Bliesner, B. L., Timmermann, A., and Cobb, K. M.: Evolution and forcing mechanisms of El Nino over the past 21000 years, Nature, 515, 550-553, https://doi.org/10.1038/nature13963, 2014a.

Liu, Z., Zhu, J., Rosenthal, Y., Zhang, X., Otto-Bliesner, B. L., Timmermann, A., Smith, R. S., Lohmann, G., Zheng, W., and Elison Timm, O.: The Holocene temperature conundrum, P. Natl. Acad. Sci. USA, 111, 3501-3505, https://doi.org/10.1073/pnas.1407229111, 2014b.

Ljung, K., Björck, S., Renssen, H., and Hammarlund, D.: South Atlantic island record reveals a South Atlantic response to the 8.2 kyr event, Clim. Past, 4, 35-45, https://doi.org/10.5194/cp-435-2008, 2008.

Ma, Z. X., Huang, J. H., Wei, Y., Li, J. H., and Hu, C. Y.: Organic carbon isotope records of the Poyang Lake sediments and their implications for the paleoclimate during the last 8 ka, Geochimica, 33, 279-285, https://doi.org/10.19700/j.03791726.2004.03.007, 2004 (in Chinese).

Marchant, R. and Hooghiemstra, H.: Rapid environmental change in African and South American tropics around 4000 years before present: a review, Earth-Sci. Rev., 66, 217-260, https://doi.org/10.1016/j.earscirev.2004.01.003, 2004. 
Matero, I. S. O., Gregoire, L. J., Ivanovic, R. F., Tindall, J. C., and Haywood, A. M.: The 8.2 ka cooling event caused by Laurentide ice saddle collapse, Earth Planet. Sc. Lett., 473, 205-214, https://doi.org/10.1016/j.epsl.2017.06.011, 2017.

Mayewski, P. A., Rohling, E. E., Curt Stager, J., Karlén, W., Maasch, K. A., Meeker, L. D., Meyerson, E. A., Gasse, F., van Kreveld, S., Holmgren, K., Lee-Thorp, J., Rosqvist, G., Rack, F., Staubwasser, M., Schneider, R. R., and Steig, E. J.: Holocene Climate Variability, Quaternary Res., 62, 243-255, https://doi.org/10.1016/j.yqres.2004.07.001, 2004.

Morrill, C., LeGrande, A. N., Renssen, H., Bakker, P., and Otto-Bliesner, B. L.: Model sensitivity to North Atlantic freshwater forcing at $8.2 \mathrm{ka}$, Clim. Past, 9, 955-968, https://doi.org/10.5194/cp-9-955-2013, 2013.

Morrill, C., Ward, E. M., Wagner, A. J., Otto-Bliesner, B. L., and Rosenbloom, N.: Large sensitivity to freshwater forcing location in $8.2 \mathrm{ka}$ simulations, Paleoceanography, 29, 930-945, https://doi.org/10.1002/2014pa002669, 2014.

Nakamura, A., Yokoyama, Y., Maemoku, H., Yagi, H., Okamura, M., Matsuoka, H., Miyake, N., Osada, T., Adhikari, D. P., Dangol, V., Ikehara, M., Miyairi, Y., and Matsuzaki, H.: Weak monsoon event at $4.2 \mathrm{ka}$ recorded in sediment from Lake Rara, Himalayas, Quatern. Int., 397, 349-359, https://doi.org/10.1016/j.quaint.2015.05.053, 2016.

Ning, L., Liu, J., Bradley, R. S., and Yan, M.: Comparing the spatial patterns of climate change in the 9th and 5th millennia?BP from TRACE-21 model simulations, Clim. Past, 15, 4152, https://doi.org/10.5194/cp-15-41-2019, 2019.

Owen, L. A. and Dortch, J. M.: Nature and timing of Quaternary glaciation in the HimalayanTibetan orogen, Quaternary Sci. Rev., 88, 14-54, https://doi.org/10.1016/j.quascirev.2013.11.016, 2014.

Peltier, W. R.: GLOBAL GLACIAL ISOSTASY AND THE SURFACE OF THE ICE-AGE EARTH: The ICE-5G (VM2) Model and GRACE, Annu. Rev. Earth Pl. Sc., 32, 111-149, https://doi.org/10.1146/annurev.earth.32.082503.144359, 2004.

Peng, Y., Xiao, J., Nakamura, T., Liu, B., and Inouchi, Y.: Holocene East Asian monsoonal precipitation pattern revealed by grainsize distribution of core sediments of Daihai Lake in Inner Mongolia of north-central China, Earth Planet. Sc. Lett., 233, 467479, https://doi.org/10.1016/j.eps1.2005.02.022, 2005.

Ramos-Román, M. J., Jiménez-Moreno, G., Camuera, J., GarcíaAlix, A., Anderson, R. S., Jiménez-Espejo, F. J., and Carrión, J. S.: Holocene climate aridification trend and human impact interrupted by millennial- and centennial-scale climate fluctuations from a new sedimentary record from Padul (Sierra Nevada, southern Iberian Peninsula), Clim. Past, 14, 117-137, https://doi.org/10.5194/cp-14-117-2018, 2018.

Rimbu, N., Lohmann, G., Lorenz, S. J., Kim, J. H., and Schneider, R. R.: Holocene climate variability as derived from alkenone sea surface temperature and coupled oceanatmosphere model experiments, Clim. Dynam., 23, 215-227, https://doi.org/10.1007/s00382-004-0435-8, 2004.

Roland, T. P., Caseldine, C. J., Charman, D. J., Turney, C. S. M., and Amesbury, M. J.: Was there a " $4.2 \mathrm{ka}$ event" in Great Britain and Ireland? Evidence from the peatland record, Quaternary Sci. Rev., 83, 11-27, https://doi.org/10.1016/j.quascirev.2013.10.024, 2014.
Rupper, S., Roe, G., and Gillespie, A.: Spatial patterns of Holocene glacier advance and retreat in Central Asia, Quaternary Res., 72, 337-346, https://doi.org/10.1016/j.yqres.2009.03.007, 2009.

Sachs, J. P.: Cooling of Northwest Atlantic slope waters during the Holocene, Geophys. Res. Lett., 34, L03609, https://doi.org/10.1029/2006gl028495, 2007.

Shakun, J. D., Clark, P. U., He, F., Marcott, S. A., Mix, A. C., Liu, Z., Otto-Bliesner, B., Schmittner, A., and Bard, E.: Global warming preceded by increasing carbon dioxide concentrations during the last deglaciation, Nature, 484, 49-54, https://doi.org/10.1038/nature10915, 2012.

Shanahan, T. M., Overpeck, J. T., Anchukaitis, K. J., Beck, J. W., Cole, J. E., Dettman, D. L., Peck, J. A., Scholz, C. A., and King, J. W.: Atlantic forcing of persistent drought in West Africa, Science, 324, 377-380, 2009.

Sigl, M., Severi, M., and McConnell, J. R.: A role for volcanoes in causing the "4.2 ka BP event"?, The $4.2 \mathrm{ka}$ BP event: an international workshop, 10-12 January 2018, Pisa, Italy, 2018.

Solomina, O. N., Bradley, R. S., Hodgson, D. A., IvyOchs, S., Jomelli, V., Mackintosh, A. N., Nesje, A., Owen, L. A., Wanner, H., Wiles, G. C., and Young, N. E.: Holocene glacier fluctuations, Quaternary Sci. Rev., 111, 9-34, https://doi.org/10.1016/j.quascirev.2014.11.018, 2015.

Staubwasser, M. and Weiss, H.: Holocene Climate and Cultural Evolution in Late Prehistoric-Early Historic West Asia, Quaternary Res., 66, 372-387, https://doi.org/10.1016/j.yqres.2006.09.001, 2006.

Staubwasser, M., Sirocko, F., Grootes, P. M., and Segl, M.: Climate change at the $4.2 \mathrm{kaBP}$ termination of the Indus valley civilization and Holocene south Asian monsoon variability, Geophys. Res. Lett., 30, 1425, https://doi.org/10.1029/2002gl016822, 2003.

Tan, L. C., An, Z. S., Cai, Y. J., and Long, H.: The Hydrological Exhibition of $4.2 \mathrm{kaBP}$ Event in China and Its Global Linkages, Geol. Rev., 54, 94-104, https://doi.org/10.16509/j.georeview.2008.01.010, 2008 (in Chinese).

Tan, L. C., Cai, Y. J., Cheng, H., Edwards, L. R., Gao, Y. L., Xu, H., Zhang, H. W., and An, Z. S.: Centennial- to decadal- scale monsoon precipitation variations in the upper Hanjiang River region, China over the past 6650 years, Earth Planet. Sc. Lett., 482, 580-590, https://doi.org/10.1016/j.eps1.2017.11.044, 2018.

Thompson, L. G., Mosley-Thompson, E., Davis, M., Henderson, K. A., Brecher, H., Zagorodnov, V. S., Mashiotta, T., Lin, P. N., Mikhalenko, V. N., Hardy, D. R., and Beer, J.: Kilimanjara Ice Core Records: Evidence of Holocene Climate Change in Tropical Africa, Science, 298, 589-593, https://doi.org/10.1126/science.1073198, 2002.

Tremblay, L. B., Mysak, L. A., and Dyke, A. S.: Evidence from driftwood records for century-to-millennial scale variations of the high latitude atmospheric circulation during the Holocene, Geophys. Res. Lett., 24, 2027-2030, https://doi.org/10.1029/97g102028, 1997.

Turney, C., Baillie, M., Clemens, S., Brown, D., Palmer, J., Pilcher, J., Reimer, P., and Leuschner, H. H.: Testing solar forcing of pervasive Holocene climate cycles, J. Quaternary Sci., 20, 511-518, https://doi.org/10.1002/jqs.927, 2005. 
Vellinga, M. and Wood, R. A.: Global climatic impacts of a collapse of the Atlantic Thermohaline Circulation, Clim. Change, 54, 251-267, 2002.

Wagner, A. J., Morrill, C., Otto-Bliesner, B. L., Rosenbloom, N., and Watkins, K. R.: Model support for forcing of the $8.2 \mathrm{ka}$ event by meltwater from the Hudson Bay ice dome, Clim. Dynam., 41, 2855-2873, https://doi.org/10.1007/s00382-013-1706-z, 2013.

Walker, M. J. C., Berkelhammer, M., Björck, S., Cwynar, L. C., Fisher, D. A., Long, A. J., Lowe, J. J., Newnham, R. M., Rasmussen, S. O., and Weiss, H.: Formal subdivision of the Holocene Series/Epoch: a Discussion Paper by a Working Group of INTIMATE (Integration of ice-core, marine and terrestrial records) and the Subcommission on Quaternary Stratigraphy (International Commission on Stratigraphy), J. Quaternary Sci., 27, 649-659, https://doi.org/10.1002/jqs.2565, 2012.

Wang, S. W.: Holocene cold events in the North Atlantic: Chronology and Climate Impact, Quaternary Sci., 29, 1146-1153, 2009 (in Chinese).

Wang, S. W.: 4.2 ka BP Event, Advances in Climate Change Research, 6, 75-76, 2010 (in Chinese).

Wang, Y. J., Cheng, H., Edwards, L. R., He, Y. Q., Kong, X. G., An, Z. S., Wu, J. Y., Kelly, M., Dykoski, C. A., and Li, X. D.: The Holocene Asian Monsoon: Links to Solar Changes and North Atlantic Climate, Science, 308, 854-857, 2005.

Wanner, H., Beer, J., Bütikofer, J., Crowley, T. J., Cubasch, U., Flückiger, J., Goosse, H., Grosjean, M., Joos, F., Kaplan, J. O., Küttel, M., Müller, S. A., Prentice, I. C., Solomina, O., Stocker, T. F., Tarasov, P., Wagner, M., and Widmann, M.: Mid- to Late Holocene climate change: an overview, Quaternary Sci. Rev., 27, 1791-1828, https://doi.org/10.1016/j.quascirev.2008.06.013, 2008.

Weiss, H.: Megadrought, Collapse, and Resilience in late 3rd millennium BC Mesopotamia, 7th Archaeological Conference of Central Germany, 23-26 October 2014, Halle (Saale), Germany, 2015.
Weiss, H.: Global megadrought, societal collapse and resilience at $4.2-3.9 \mathrm{kaBP}$ across the Mediterranean and west Asia, Past Global Change Magazine, 24, 62-63, https://doi.org/10.22498/pages.24.2.62, 2016.

Weiss, H. and Bradley, R. S.: What drives societal collapse?, Science, 291, 609-610, 2001.

Weiss, H., Courty, M. A., Wetterstrom, W., Guichard, F., Senior, L., Meadow, R., and Curnow, A.: The Genesis and Collapse of Third Millennium North Mesopotamian Civilization, Science, 261, 995-1004, https://doi.org/10.1126/science.261.5124.995, 1993.

Wu, W. X. and Liu T. S.: 4000 a BP Event and its implications for the origin of Ancient Chinese Civilization, Quaternary Sci., 21, 443-451, 2001 (in Chinese).

$\mathrm{Wu}, \mathrm{W}$. X. and Liu, T. S.: Possible role of the "Holocene Event 3" on the collapse of Neolithic Cultures around the Central Plain of China, Quatern. Int., 117, 153-166, https://doi.org/10.1016/s1040-6182(03)00125-3, 2004.

Yang, X., Scuderi, L. A., Wang, X., Scuderi, L. J., Zhang, D., Li, H., Forman, S., Xu, Q., Wang, R., Huang, W., and Yang, S.: Groundwater sapping as the cause of irreversible desertification of Hunshandake Sandy Lands, Inner Mongolia, northern China, P. Natl. Acad. Sci. USA, 112, 702-706, 2015.

Yechieli, Y., Magaritz, M., Levy, Y., Weber, U., Kafri, U., Woelfli, W., and Bonani, G.: Late Quaternary Geological History of the Dead Sea Area, Israel, Quaternary Res., 39, 59-67, https://doi.org/10.1006/qres.1993.1007, 1993.

Zhang, R. and Delworth, T. L.: Simulated Tropical Response to a Substantial Weakening of the Atlantic Thermahaline Circulation, J. Climate, 18, 1853-1860, 2005.

Zhang, R. and Delworth, T. L.: Impact of Atlantic multidecadal oscillations on India/Sahel rainfall and Atlantic hurricanes, Geophys. Res. Lett., 33, L17712, https://doi.org/10.1029/2006gl026267, 2006. 